\title{
Analýza populizmu podl'a Ernesta Laclaua
}

\section{Analysis of populism by Ernesto Laclau}

\section{Barbara Biháryová}

\begin{abstract}
Abstrakt
Populizmus dnes predstavuje často skloňovaný pojem tak na akademickej pôde, ako i na samotnej politickej scéne, v médiách a medzi laickou verejnost'ou. Skutočnostou je, že hoci v našej spoločnosti tento pojem používa takmer každý, len málokto vie, čo vlastne znamená.

$\checkmark$ tomto článku sa preto budeme zaoberat' otázkou, ktorá sa stala predmetom analýz mnohých teoretikov, otázkou, čo je to populizmus. Jedným z tých teoretikov je Ernesto Laclau (1935-2014), ktorý populizmus nechápe ako ideológiu, ale ako istú stratégiu resp. spôsob komunikácie.

$\checkmark$ prvej časti nášho článku vymedzíme pojem „populizmus”, pričom upozorníme na jeho viaceré rozličné interpretácie ako aj na to, aké je jeho spoločné základné analytické jadro. $V$ nasledujúcich častiach článku sa už zameriame na analýzu populizmu podl'a Ernesta Laclaua.
\end{abstract}

Ciel’om nášho článku je teda analýza teórie populizmu podl'a E. Laclaua v kontexte súčasnej situácie na domácej i svetovej, nielen politickej scéne.

\section{Kl'účové slová}

populizmus, analytické jadro, l'ud a elita, Laclau, stratégia a spôsob komunikácie, požiadavky

\begin{abstract}
Populism nowadays is often used concept both in the academic field, as well as on the political scene itself, in the media and among the general public. The fact is that although almost everybody uses this term in our society, only few know what it really means.

This article will therefore deal with a question that has been the subject of many theorists' analysis, the question what populism means. One of the theorists is Ernesto Laclau (1935-2014) which does not understand populism as ideology, but as some special strategy or way of communication.
\end{abstract}


In the first part of our article we will define the term "populism", highlight its multiple interpretations as well as its common analytical core. In the following sections of the article, we will focus on the analysis of populism by Ernest Laclau.

The aim of our article is therefore to analyze the theory of populism according to E. Laclau in the context of the current situation on the domestic and global political scene.

\section{Keywords}

populism, analytical core, people and elite, Laclau, strategy and way of communication, demands

\section{Pojem a charakteristika populizmu}

Populizmus je pojmom, ktorý sa dnes vel'mi často stáva predmetom diskusií nielen v oblasti politiky, ale aj v akademických kruhoch, v médiách a v rámci samotnej verejnosti. Niet ale pochýb o tom, že mnoho z diskutérov, najmä v médiách a medzi laikmi, ani nevie, čo pojem „populizmus“ presne znamená. Náš článok sa preto zameriava na jednu z najznámejších teórií populiz$\mathrm{mu}$, na teóriu populizmu podla Ernesta Laclaua.

Na rozdiel od vágneho a pejoratívneho využívania populizmu predovšetkým médiami a politikmi, Laclau chápe pojem populizmu nie ako špecifickú ideológiu, ale skôr ako formu vyjadrovania ludu, ktorá je typická v krízových momentoch, tzn. ked' l’ud vzhl'adom na konanie či skôr nekonanie elity, ktorú zväčša predstavujú skorumpovaní politici a neefektívne byrokratické štátne inštitúcie, pocituje nespokojnost̉ a frustráciu. Laclauova koncepcia populizmu sa tak stáva vel'mi užitočnou, pretože ani my sa dnes nevieme ubránit pocitom frustrácie, nespokojnosti a sklamania zo súčasného diania na spoločensko-politickej scéne doma i v zahraničí. Laclauova teória populizmu nám umožňuje lepšie pomenovat a pochopit príčiny vzniku tohto nežiaduceho stavu v spoločnosti. Ale nielen to. Nastoluje i nasledujúce otázky: Kto alebo aké inštitúcie tvoria zdroj našej frustrácie? V akom momente sa naše požiadavky stávajú bojovnými požiadavkami? Ako dospiet' k riešeniu našej frustrácie a nespokojnosti, t. j. ako prinútit elity, aby našim požiadavkám vyhoveli? Avšak, predtým ako sa pokúsime odpovedat na tieto a iné otázky, resp. bližšie predstavit samotnú analýzu teórie populizmu podla E. Laclaua, sa v prvej časti nášho článku budeme snažit objasnit význam a základnú charakteristiku populizmu. Existuje niekol'ko interpretácií pojmu „populizmus“. 
Za tie najčastejšie však považujeme tri. Po prvé, populizmus sa považuje za špecifický štýl komunikácie, ktorý sa vyznačuje vysokou emocionalitou, jednoduchostou a zameranostou na primárne inštinkty voličov, pričom im ponúka jednoduché riešenia na zložité problémy. Po druhé, populizmus sa interpretuje ako oportunistická politika, ktorej ciel’om je rýchle uspokojenie voličov. V tejto súvislosti sa často stretávame s nezodpovednou, redistributívnou politikou, prostredníctvom ktorej si politici podporu svojich voličov „kupujú“. A napokon po tretie, populizmus je interpretovaný ako istá forma vodcovského štýlu, pomocou ktorého charizmatický líder mobilizuje svojich sympatizantov. ${ }^{1}$ Ako upozorňuje Nociar, predovšetkým prvé dve zo spomínaných interpretácií sú pejoratívne, normatívne a problematické z hl'adiska operacionalizácie a možno ich opísat vhodnejšími termínmi ako „demagógia“ či „oportunizmus“..2 Všetky uvedené interpretácie sú vel’mi rozšírené, a to najmä v médiách a medzi laickou verejnostou. V skutočnosti však nezachytávajú podstatu toho, ako je populizmus charakterizovaný v odborných akademických kruhoch. Na druhej strane treba ale povedat, že toto zamieňanie termínov v bežnom diskurze sa čiastočne premieta aj do odbornej diskusie.

Ako sme sa už vyššie zmienili, na základe zamieňania populizmu s demagógiou je populizmus častokrát apriori vnímaný ako negatívny fenomén. Takýto postoj potom aj negatívne ovplyvňuje diskusie o vztahu medzi populizmom a demokraciou. Negatívne konotácie sa tiež odrážajú aj v interpretácii a v používaní termínu „populistická politická strana“ ako aj v prípade označenia nejakého jednotlivca za populistu. Tieto negatívne konotácie pojmu „populizmus“ sú príčinou aj jeho komplikovaného vymedzenia vo vedeckej oblasti. Okrem problému pri označovaní politických straníckych subjektov, ktoré bývajú označované za populistické, sa stretávame aj so stotožňovaním populizmu s nacionalizmom či pravicovým extrémizmom. V tomto kontexte je však potrebné upozornit’, že vzhladom na skutočné pôsobenie nielen politických subjektov môžeme

1 Porovnaj Cass Mudde, The populist Zeitgeist, Government and Opposition 39, 2004, č. 4, s. 541-563. Cass Mudde, Are Populists Friends or Foes of Constitutionalism? [online, cit. 13. 3. 2018], dostupné na <http://www.fljs.org/sites/www.fljs.org/files/publications/Mudde_0.pdf>.

2 Tomáš Nociar, Politológov sprievodca „terminologickým chaosom“: terminológia, charakteristika a konceptualizácia krajnepravicovej ideologickej rodiny, Rexter - časopis pro výzkum radikalismu, extremismu a terorismu 14, 2016, č. 1, s. 44-91: 58 [online, cit. 13. 3. 2018], dostupné na <http://www.rexter.cz/politologov-sprievodca-terminologickym-chaosom-terminologia-charakteristika-a-konceptualizacia-krajnepravicovej-ideologickej-rodiny/2016/05/08/>. 
tvrdit, že nie každý populista je extrémista, ale každý extrémista môže zároveň aj vykazovat populistické prvky. K nejednoznačnosti pojmu „populizmus" však prispieva i vytváranie jeho rôznych typológií ako napr. výlučný/uzavretý populizmus, nacionálny populizmus, nový populizmus, xenofóbny populizmus či nacionalistický populizmus. Tieto sú totiž mnohokrát svojím významom vzdialené, ba dokonca v rozpore s prevládajúcim poňatím populizmu v odbornej literatúre. Problémy pri interpretácii a používaní daného pojmu však nastávajú aj vtedy, ked' pri zachytávaní rovnakého fenoménu alebo presnejšie povedané rovnakého typu politických subjektov sa v odbornom diskurze používajú odlišné termíny či klasifikačné schémy s podobným významom ako napr. anti-political establishment parties, anti-party parties, anti-mainstream parties, protest parties, discontent parties, unorthodox parties alebo tiež antisystémové strany. ${ }^{3}$

Napriek vyššie uvedeným problémom pri interpretácii pojmu „populizmus" sa väčšina autorov zaoberajúcich sa populizmom zhodla na jeho štyroch základných a navzájom úzko prepojených charakteristikách. ${ }^{4}$ Po prvé, lud a elita tvoria v spoločnosti homogénne skupiny; po druhé, medzi ludom a elitou panuje antagonistický vztah; po tretie, lud je hodnotený pozitívne a elita negatívne; a po štvrté, lud je chápaný ako morálne neskazený suverén. Uvedené charakteristiky vytvárajú tzv. analytické jadro populizmu.

\section{Analytické jadro populizmu}

V súvislosti s prvou charakteristikou analytického jadra si je potrebné uvedomit’, že základným pojmom populizmu je lud, ktorý je vnímaný ako monolitická alebo homogénna skupina so spoločnými záujmami. V rámci krajne pravicového populizmu sa stretávame s etnickou koncepciou ludu. To znamená, že zo svojho konceptu vylučuje spolu s elitami aj iné časti spoločnosti, a to predovšetkým menšiny. Tie sú charakterizované na etnickej, národnej,

3 Vlastimil Havlík - Aneta Pinková, Populisté, protestní strany, outsideři? Několik poznámek ke konceptualizaci populistických politických stran, Rexter - časopis pro výzkum radikalismu, extremismu a terorismu 10, 2012, č. 2, s. 121-153 [online, cit. 13. 3. 2018], dostupné na <http://www.rexter.cz/populiste-protestni-strany-outsideri-nekolik-poznamek-ke-konceptualizaci-populistickych-politickych-stran/2012/11/11/>.

4 Medzi tých najznámejších patria autori ako C. Mudde, M. Canovan, P. Taggart či Ch. Moufe a E. Laclau. 
náboženskej alebo rasovej báze. Koncept l’udu sa tak v populistickom krajne pravicovom diskurze stáva teritoriálnym, etnicky a kultúrne špecifikovaným. $\mathrm{Z}$ uvedeného podla nášho názoru vyplýva, že l’ud je v tomto prípade považovaný za národ, ktorý je tvorený jednotlivcami zdielajúcimi jasné rasové a kultúrne atribúty. Takýmto nativistickým pohladom na to, kto patrí do ludu a kto nie, sa podla Nociara vytvárajú národné komunity, čo takisto môže vyústit' okrem iného aj do xenofóbie. ${ }^{5}$

Podla druhej spomínanej charakteristiky analytického jadra populizmu je l’ud vymedzovaný v protiklade k vládnucej elite. Tá sleduje len svoje vlastné záujmy, pričom obmedzuje záujmy a demokratické práva ludu. Na základe toho môžeme usúdit, že podstatou populizmu sa stáva diskurzívna konštrukcia nepriatela. Práve takýto nepriatel'sky ladený diskurz voči vládnucej elite nad’alej udržiava ideu ludu, ktorý sa napriek situácii snaží presadzovat svoje záujmy. ${ }^{6} \mathrm{~V}$ tomto zmysle tiež môžeme tvrdit, že občania sú nereprezentovaní nimi zvolenými elitami. Predstavitelia populizmu preto vyjadrujú rozhorčenie s establishmentom, elitou či mocenským blokom, tzn. jednoducho s tým, kto disponuje vládnou mocou. Prezentujú sa tak ako zástancovia „čistej“ politiky, vystupujú proti korupcii a tvrdia, že práve oni dokážu napravit’ onen antagonistický vztah medzi ludom a elitou. Je dôležité uvedomit’ si, že hoci populizmus kritizuje vládnucu elitu a mechanizmy systému zastupitel'skej demokracie, nevystupuje proti samotnej demokracii. Populisti teda nespochybňujú demokratické princípy. Výnimkou sú samozrejme krajne pravicovo orientovaní populisti.

Na základe uvedeného je však zrejmé, že všetky typy populizmu sa odvolávajú na pozitívne vnímaný l’ud, no zároveň sa negatívne vymedzujú voči elitám, ktoré častokrát označujú za skorumpované.

V súvislosti s poslednou charakteristikou analytického jadra populizmu upozorňujeme na skutočnost', že jeho predstavitelia sa považujú za jediného dôveryhodného obhajcu záujmov ludu, pričom ten vystupuje ako morálne neskazený suverén. Podla predstavitelov populizmu skorumpované vládnuce elity zbavili lud moci, ktorú zneužívajú vo svoj vlastný prospech. Populisti preto poskytujú isté riešenia, prostredníctvom ktorých by bolo možné oslabit moc skorumpovaných a nekompetentných elít. Tento ciel považujú za najdôležitejší, pričom tvrdia, že reprezentujú a obhajujú záujmy „obyčajných“ ludí.

5 T. Nociar, Politológov sprievodca „terminologickým chaosom“..., s. 59.

6 Ernesto Laclau, What's in a Name?, in Panizza, F. (ed.), Populism and the Mirror of Democracy, London - New York: Verso, 2005, s. 32-50. 
Napriek tu predstavenému analytickému jadru populizmu, s ktorým sa stretávame v koncepciách mnohých autorov zaoberajúcich sa populizmom, panujú v odbornej akademickej obci rozdielne názory na to, či populizmus je alebo nie je ideológiou. Ako sme už vyššie spomenuli, jedným z autorov, ktorí zastávajú stanovisko, že populizmus nemožno považovat za ideológiu, je práve Ernesto Laclau.

\section{Prečo populizmus nie je ideológiou?}

Ernesto Laclau (1935-2014) bol významný filozof, politológ a univerzitný profesor politických vied. Doktorandské štúdium absolvoval na Univerzite v Oxforde. Na Univerzite v Essexe založil teoretickú školu venovanú analýze diskurzívnej ideológie. Spolu so svojou manželkou, belgickou politickou filozofkou, Chantal Mouffe (*1943) bol predstavitelom postmarxizmu. Vo svojej hlavnej práci Hegemony and Socialist Strategy (1985) predstavili svoje chápanie politiky ako boja o zmysel, tzn. význam. Toto chápanie sa však nevyznačuje ani diskusiou o tom, čo je pravdivé alebo nie, ani o pozíciách, ktoré už existujú či boli vytvorené v iných oblastiach. Vyznačuje sa skôr praxou artikulácie, ktorá konštruuje jednu alebo druhú pozíciu, resp. jeden alebo druhý význam na základe faktov. Tie môžu nadobudnút vel’mi odlišný význam, a to podla toho, ako sú vyberané, zoskupované a najmä protichodné.

Skôr než prejdeme k samotnej analýze populizmu podla Laclaua, zameriame sa na jeho argumenty podporujúce záver, že populizmus nie je ideológiou.

V prípade, že pojmu „populizmus“ pripíšeme akýkolvek ideologický obsah, pri pokuse definovat ho sa ocitneme v záplave výnimiek a problémov. Nie je totiž bezprostredne zrejmé, aký populizmus označíme za ideológiu, pretože niektoré ideológie ako napr. fašizmus, komunizmus, socializmus, liberalizmus sa môžu vyznačovat’ aj určitými prvkami populizmu. To znamená, že „čistý“ populizmus ako ideológia neexistuje. V tomto kontexte Laclau tvrdí, že je priam nemožné „najít onu poslední pevnost, v níž bychom nalezli ,čistý populismus', neredukovatelný na ony ostatní alternativní charakterizace“.7 Z toho vyplýva, že pojem „populizmus“ nie je možné presne definovat, a to ani ako ideológiu, pretože populizmus nemožno vymedzit pomocou

7 Ernesto Laclau, Emancipace a radikálni demokracie, prel. Jan Bíba - Josef Fulka, Praha: Karolinum, 2013, s. 180 . 
obsahov výpovedí, ale spôsobom, akým sú tieto obsahy zdelované. Z toho vyplýva, že populizmus môžeme považovat za akúsi komunikačnú stratégiu, v prípade politiky resp. politickej praxe.

Ako sme už spomínali, v súčasnosti, ked' je pojem „populizmus“ tak často skloňovaný či už medzi samotnými politikmi, alebo v médiách, je väčšinou vnímaný negatívne a vyvoláva búrlivé emócie. Vidíme to napríklad v politických diskusiách, ked’ jeden politik označí toho druhého za populistu, pričom pojem „populista“ je chápaný ako nadávka. Takéto negatívne uchopovanie pojmu „populizmus“ je jednou z príčin jeho problematického teoretického vymedzenia. Ak sa však pozrieme na vystupovanie predstavitelov niektorých politických strán, ktorých môžeme vzhl’adom na štyri základné charakteristiky analytického jadra populizmu ${ }^{8}$ označit za populistov, pozorujeme, že ich hlavným prostriedkom, ako na seba upozornit lud, je vyvolávat' v ňom negatívne emócie voči vládnucej skorumpovanej elite. Obrazom toho je nejaký líder politickej strany, skúsený rečník, ktorý stojí pred davom ludí na námestiach alebo vystupuje pred televíznymi kamerami na tlačovej besede a s vášňou hovorí o tom, ako nás predstavitelia vládnucej elity vykoristujú a okrádajú, pričom sám sl’ubuje l’ud’om, že práve on, resp. príslušná strana, je zárukou čestnosti a transparentnosti. Častokrát však ponúka jednoduché riešenia na zložité problémy, čo sa v konečnom dôsledku môže ukázat’ ako nefunkčné.

Hoci populizmus útočí najmä na našu emocionálnu stránku, Buraj upozorňuje, že „niekedy sa populisti naopak odvolávajú na rozum a vyzývajú nedat sa citovo vydierat' (povedzme nejakými tragickými zábermi utopeného dietata imigranta)“. ${ }^{9}$ Takýto hlas rozumu môžeme považovat za nástroj vypočítavej kalkulácie. Buraj takisto upozorňuje, že takáto „túžba nastolit vládu rozumu môže v tejto podobe skrývat' nebezpečenstvo organizovaného kolektívneho násilia voči všetkým tým, ktorí nezodpovedajú kritériám (normám) určitého sociálneho/politického poriadku“. ${ }^{10}$

Pre Laclaua nie je pojem „populizmus“ ani pozitívny, ani negatívny. Populizmus možno podla neho jednoducho považovat za jednu zo spoločenských

8 Pozri kap. „Pojem a charakteristika populizmu“.

9 Ivan Buraj, Pokus o teoretické uchopenie populizmu, in Veda, racionalita a hodnoty [elektronický zdroj], Bratislava: Stimul, 2016, s. 36-46: 37 [online, cit. 25. 2. 2018], dostupné na <http://veshod.sk/wp-content/uploads/2016/10/pokus_o_teoreticke_uchopenie_populizmu-buraj.pdf>.

Tamtiež, s. 38. 
logík artikulácie menších spoločenských jednotiek ako predstavuje skupina. ${ }^{11}$ Základnou kategóriou tejto logiky sú požiadavky, o ktorých bude bližšie pojednávat’ nasledujúca čast̉ našej práce.

\section{„Požiadavka" ako východisko Laclauovej analýzy populizmu}

Pri analýze populizmu podla E. Laclaua je nevyhnutné najskôr definovat jej základnú kategóriu, tzn. kategóriu požiadavky. Čo pre Laclaua predstavuje „požiadavka“ a ako súvisí s populizmom? Pokúsime sa odpovedat’ v tejto časti nášho článku.

Laclau kategóriu požiadavky chápe ako základnú formu budovania sociálnej interakcie, pričom rozlišuje jej dva typy - požiadavka ako žiadost’ a požiadavka ako aktívnejšie predloženie žiadosti. Pod výrazom „požiadavka ako žiadost' si môžeme predstavit’ situáciu, ked’ sa nejaká skupina l'udí obráti so svojou konkrétnou požiadavkou na príslušnú inštitúciu, ktorá danej požiadavke napokon vyhovie. V tom prípade pocitujú žiadatelia uspokojenie. Naopak čo sa týka požiadavky ako aktívnejšieho, tzn. opakovaného predloženia žiadosti, príslušná inštitúcia ju nielenže nerieši, ale dokonca ju riešit’ odmieta. V prípade, že tieto opakovane predkladané požiadavky zostávajú nevypočuté, ludia pocitujú nespokojnost’ a frustráciu. Tá sa zväčšuje s tým, ako ich daná inštitúcia odmieta uspokojit. Zo spomenutých dvoch druhov požiadaviek vznikajú aj dve logiky, t. j. logika diferencie a logika ekvivalencie. V tejto súvislosti je však dôležité upozornit na skutočnost', že Laclau tu pod pojmom „logika“ nerozumie vednú disciplínu o správnom myslení, ale spôsob ako sú artikulované požiadavky, resp. ako je utváraný ich význam. Pri logike diferencie je význam požiadaviek konštruovaný na základe vztahu diferencie, tzn. rozdielnosti, zatial' čo pri logike ekvivalencie na základe vztahu ekvivalencie, tzn. rovnocennosti. Presnejšie povedané, pri logike diferencie je každá jedna požiadavka od tej druhej oddelená, resp. všetky sú izolované, a preto netvoria retazec. Naopak pri logike ekvivalencie sú požiadavky vzájomne previazané vztahom ekvivalencie, tzn. rovnocennosti, pričom tvoria rełazec. ${ }^{12}$

Ako sme už vy̌šsie spomínali, ak nejaká spoločenská požiadavka nadobudne podobu žiadosti, nie je uspokojená vd’aka samospráve, ale prostredníctvom apelu k inej inštancii, ktorá rozhoduje rozhodovacou mocou. To,

11 E. Laclau, Emancipace a radikálni demokracie.., s. 181.

12 Tamtiež, s. 183-184. 
že k žiadosti skutočne dôjde, poukazuje na to, že rozhodovacia moc vy̌šsej inštancie nie je spochybnená. Požiadavka ako žiadost́ predstavuje izolovanú požiadavku, tzn. v sebe samej. Laclau v tejto súvislosti vyslovuje záver, že „žádosti tohoto typu, v nichž jsou požadavky izolované nebo individuálně uspokojované, nevytvářejí v rámci sociálna žádnou propast nebo hranici““. ${ }^{13}$ Sociálni aktéri práve naopak prijímajú legitimitu ktorejkolvek z inštancií procesu. Tieto spoločenské logiky, tzn. logiky, ktoré fungujú v súlade s inštitucionalizovaným, diferenčným modelom, Laclau nazýva logikami diferencie. Ako už bolo povedané, význam predkladaných požiadaviek je tu vytváraný na základe vzţahu diferencie, tzn. tým, že sú tieto požiadavky od seba izolované, každá jedna nadobúda odlišný význam. Takéto logiky predpokladajú, že nejestvuje nijaká spoločenská trhlina či priepast', pretože požiadavky, resp. žiadosti, ktoré sú na základe nich predkladané, sú príslušnými inštitúciami splnené. ${ }^{14}$

V prípade druhého, vyššie spomenutého typu požiadavky, t. j. požiadavky ako aktívnejšieho, teda opakovaného predkladania žiadosti, ktorá je napokon zamietnutá, bez pochyby vzniká stav spoločenskej frustrácie. Jedna nevyriešená požiadavka ale nemá za následok nijaké zásadné zmeny. Ak však existuje vel'ká škála neriešených požiadaviek, mnohonásobné sklamanie stojí za vznikom sociálnych logík celkom odlišného druhu. Tým, že sú tieto požiadavky neriešené, vyznačujú sa určitou mierou negatívnosti. Takáto situácia, tzn. situácia, v ktorej sa nahromad’ujú nesplnené požiadavky, predstavuje prvú podmienku politickej artikulácie populizmu. V tomto prípade sa stretávame s logikou ekvivalencie, pričom nesplnené požiadavky vytvárajú už vyššie spomínaný tzv. ekvivalenčný retazec, v ktorom sú jednotlivé požiadavky utvárané na základe vztahu ekvivalencie, tzn. rovnocennosti. ${ }^{15}$

Tento neustále sa predlžujúci retazec nesplnených požiadaviek je príčinou vzniku spoločenskej trhliny, ktorá sa spolu s ním zväčšuje. Hlavný rozdiel medzi logikou ekvivalencie a logikou diferencie teda spočíva v tom, či sú dané požiadavky príslušnou inštitúciou splnené alebo nie a aký vztah je medzi nimi. V tomto kontexte môžeme hovorił aj o odlišnosti subjektov požiadavky, tzn. kto túto požiadavku predkladá.

\footnotetext{
13 Tamtiež, s. 183.

14 Tamtiež, s. 183.

15 Tamtiež, s. 184.
} 


\section{Demokratický a l'udový subjekt}

Pochopitel'ne, že obe vyššie charakterizované logiky, t. j. logika diferencie a logika ekvivalencie, sa vyznačujú aj rozdielnym typom subjektov požiadavky. V prvom prípade diferenčnej logiky je subjekt požiadavky rovnako izolovaný ako sama požiadavka. Neznamená to však, že požiadavku vznáša jeden izolovaný jedinec, pretože aj požiadavky viacerých jedincov ako skupiny môžu byt nejakou inštitúciou splnené. Ak teda subjekt vznáša požiadavku, ktorej je napokon vyhovené, hovoríme o subjekte demokratickom. Opät je tu však dôležité vysvetlit Laclauovu svojskú terminológiu, tzn. prečo v tomto prípade používa práve prívlastok „demokratický“. To, že bolo požiadavkám zo strany inštitúcií vyhovené, odkazuje podla Laclaua na demokratické politické zriadenie, pretože práve v demokracii by mal nastat stav, kedy nami zvolení štátni predstavitelia akceptujú naše potreby, resp. požiadavky. V druhom prípade, t. j. v prípade logiky ekvivalencie, je subjekt na rozdiel od demokratického subjektu širší, pretože jeho subjektivita je výsledkom viacero demokratických požiadaviek, ktoré sú ale príslušnou inštitúciou ignorované. Hovoríme preto o subjekte ludovom. ${ }^{16}$ Ako sme už spomínali, jednou zo základných charakteristík populizmu je, že l’ud vystupuje proti elitám, pretože tie jeho požiadavky neriešia, ba až ignorujú. Takéto požiadavky sú predmetom ekvivalenčnej logiky, na základe ktorej vytvárajú ekvivalenčný retazec. No a práve preto Laclau užíva termín „ludový subjekt“. Odkazuje na základný ciel’ populizmu, t. j. „boj“ ludu proti elitám. Z týchto záverov okrem iného podla Laclaua vyplýva, že „čím více společenských požadavků má tendenci být diferentně včleněno do úspěšného institucionálního systému, tím slabší budou ekvivalenční vazby a tím méně pravděpodobné bude utvoření lidové subjektivity“. ${ }^{17}$ No na druhej strane takisto platí, že „situace, v níž větší množství nesplněných požadavků koexistuje se vzrůstající neschopností jejich diferentního začlenění ze strany institucionálního systému, naopak vytváří populismus vedoucí k populistické roztržce“. ${ }^{18}$ Dôsledkom tejto analýzy je, že prejavenie ludovej subjektivity nejestvuje bez vytvorenia určitej vnútornej hranice, tzn. hranice oddel'ujúcej požiadavky od inštitucionálneho systému. Podla toho, či inštitucionálny systém požiadavkám vyhovie, môžeme hovorit o sile ekvivalenčnej väzby medzi nimi. V prípade, že bolo požiadavkám zo

\footnotetext{
16 Pozri tamtiež, s. 184.

17 Tamtiež, s. 184.

18 Tamtiež, s. 185.
} 
strany inštitúcií vyhovené, tieto ekvivalenčné väzby sú príliš slabé na to, aby dokázali vytvorit ludovú subjektivitu, t. j. ludový subjekt. Ak ale inštitúcie nedokážu, ba dokonca nechcú tieto požiadavky uskutočnit, ekvivalenčné väzby v ekvivalenčnom retazci nesplnených požiadaviek sa stávajú silnejšími, čo napokon predpokladá vznik populizmu. Ako sme uvádzali v prvej časti našej práce, medzi základné charakteristiky analytického jadra populizmu patrí aj rozdelenie spoločnosti na dva tábory, t. j. na elitu a l’ud. Aj v prípade analýzy populizmu podla Laclaua môžeme tvrdit, že spoločnoste je rozdelená na dva tábory - na tých, ktorí majú moc, a na utlačovaných. Sú to práve ekvivalenčné ludové diskurzy, ktoré v momente svojho vzniku, tzn. nesplnením požiadaviek inštitucionálnym systémom, spoločnost̉ takto rozdelujú. To má za následok okrem iného aj spresnenie povahy požiadaviek, ktoré prestávajú byt’ „obyčajnými“ žiadostami a stávajú sa požiadavkami bojovnými. ${ }^{19}$

Na základe tu interpretovanej Laclauovej analýzy môžeme za štrukturálne rysy potrebné na vymedzenie populizmu považovat: ekvivalenciu, ludovú subjektivitu a dichotomické budovanie spoločnosti okolo určitej, vyššie definovanej, vnútornej hranice. Takisto je však nevyhnutné identifikovat to, čo populizmus reprezentuje. ${ }^{20}$ Touto problematikou sa budeme zaoberaţ v nasledujúcej, záverečnej časti nášho článku o analýze populizmu podla E. Laclaua, pričom vymedzíme pojem prázdneho a plávajúceho signifikantu.

\section{Prázdny a plávajúci signifikant}

Úlohu reprezentanta populizmu zaujíma v určitom momente len jedna konkrétna požiadavka $\mathrm{z}$ ekvivalenčného retazca. Táto pritom prestáva byt sama sebou a začína byt jednoducho vyjadrením ostatných nesplnených požiadaviek. Zoberme si napríklad aktuálnu situáciu na Slovensku, kedy slovenský lud žiada predčasné vol'by. Požiadavka predčasných volieb je ale len jednou z mnohých požiadaviek ekvivalenčného rełazca ako napr. objektívne a transparentné vyšetrenie vraždy novinára a jeho priatelky, odstúpenie súčasného policajného prezidenta a nový systém menovania jeho nástupcu, odpolitizovanie dôležitých funkcií v štátnej a verejnej správe, zefektívnenie a stransparentnenie systému štátnej a verejnej správy a pod. Zo všetkých týchto požiadaviek ekvivalenčného retazca sa stala práve požiadavka predčasných

19 Pozri tamtiež, s. 185.

20 Pozri I. Buraj, Pokus o teoretické uchopenie populizmu..., s. 40. 
volieb reprezentantom populizmu, pretože nespokojnost̉ l'udu spôsobená spoločenskou situáciou a neriešením vyššie uvedených požiadaviek vyústila až do požiadavky predčasných volieb.

V opozícii k ekvivalenčnému retazcu nesplnených požiadaviek, resp. jednej konkrétnej požiadavke, ktorá vystupuje v úlohe reprezentanta populizmu, stojí vládnuca moc inštitúcií. Ekvivalenčné požiadavky teda vznikajú z opozície k moci. Úlohu tzv. prázdneho signifikantu zastáva práve tá požiadavka z ekvivalenčného retazca, ktorá ho reprezentuje ako celok. Vo vyššie uvedenom príklade funkciu takéhoto signifikantu zastáva práve požiadavka predčasných volieb. V tomto zmysle ale taktiež platí, že „čím více se řetězec ekvivalencí rozšiřuje, tím slabší bude jeho spojení s partikularistickými požadavky, které přebírají funkci univerzální reprezentace“. ${ }^{21}$ Napriek tomu však môžeme tvrdit, že l’udovú subjektivitu sme schopní budovat len na základe diskurzívneho vytvárania tendenčne prázdnych signifikantov. To sa môže zdat’ ako paradox, pretože vyprázdnenost̉ populistických symbolov sa stáva podmienkou ich politickej účinnosti. Možná existencia prázdnych signifikantov teda závisí od prítomnosti určitého retaazca ekvivalenčných požiadaviek, ktorý je oddelený od mocenských inštitúcií vnútornou hranicou. Prázdny signifikant je jednoducho len jeden prvok z ekvivalenčného retazca spoločenských požiadaviek, tzn. jedna požiadavka, ktorá vytvára všeobecný univerzálny celok požiadaviek retazca, pričom ho v tomto zmysle reprezentuje. Prívlastok „prázdny“ považujeme za paradox, pretože takýmto reprezentantom môže byt skutočne l’ubovolná požiadavka z ekvivalenčného retazca, tzn. prázdny signifikant môže byt’ „vyplnený“ akýmkol'vek obsahom. Niet ale pochýb o tom, že politická dynamika populizmu je determinovaná neustálym reprodukovaním, tzn. posúvaním vyššie uvedenej vnútornej hranice. V skutočnosti môže byt táto hranica, na ktorej sa populistický diskurz zakladá, aj rozvrátená, k čomu môže dôjsţ dvomi rôznymi spôsobmi. Prvý nastáva vtedy, ked' sa pretrhnú ekvivalenčné väzby medzi rôznymi partikulárnymi požiadavkami $\mathrm{v}$ dôsledku ich uskutočnenia, čo predstavuje cestu k úpadku populizmu, a teda prechod na vyšší stupeň súdržnosti inštitucionálneho systému. To jednoducho znamená, že požiadavky z ekvivalenčného retazca boli splnené mocenským inštitucionálnym aparátom. V tom prípade populizmus ustupuje, pretože už vlastne nie je potrebný. Druhý spôsob rozvrátenia spomínanej vnútornej hranice sa nevyznačuje odstránením hraníc, ale ich zmenou. V momente, ked' sa ústredné signifikanty l'udového diskurzu

E. Laclau, Emancipace a radikálni demokracie..., s. 186. 
stávajú čiastočne prázdnymi a zároveň oslabujú svoje bývalé väzby $\mathrm{k}$ nejakým partikulárnym obsahom, tieto obsahy sa začínajú otvárat' pred radou rôznych ekvivalenčných reartikulácií. Inak povedané, so zmenou vnútornej hranice ekvivalenčného retazca dochádza k reartikulácii, t. j. k istej úprave požiadaviek. K tejto zmene môže dôjst̉ napríklad pri vývoji spoločensko-politickej situácie ako napr. pri demisii vlády. Netreba však zabúdat, že prázdne l’udové signifikanty si aj v tom prípade uchovávajú svoj radikalizmus, tzn. svoju schopnost' rozdelovat spoločnost’ na tých, ktorí majú moc, a utlačovaných. Retazec ekvivalencií sa však medzitým stáva odlišným a politický význam celej populistickej operácie tak nadobúda aj odlišný politický znak. Je nesmierne dôležité pochopit, ako proces reartikulácie prebieha. Daný proces závisí od skutočnosti, že funkčnost̉ ústredných signifikantov ludového radikalizmu sa čiastočne uchováva, pričom ale niekol'ko demokratických požiadaviek sa zarad’uje do odlišného retazca ekvivalencií, tzn. reartikulujú sa. Laclau si na základe týchto záverov uvedomuje nejednoznačnost̉ ludových, resp. prázdnych signifikantov a požiadaviek, a zavádza preto pojem tzv. plávajúceho signifikantu. Označuje takýto signifikant za „plávajúci“ z toho dôvodu, že v procese reartikulácie sa jednotlivé požiadavky po ekvivalenčnom retazci pohybujú, teda „plávajú“. To znamená, že miesto ústredného prázdneho signifikantu, ktorý reprezentuje všetky ostatné požiadavky ekvivalenčného retazca, zaujme iná požiadavka z tohto retazca. Ako sme už spomínali, v prípade, že sa zmení spoločenská situácia, ako napr. že vláda podá demisiu a prezident vymenuje novú vládu s jej novým predsedom a niektorými novými ministrami, zmení sa aj hlavná požiadavka, tzn. hlavnú požiadavku odstúpenia premiéra Fica a ministra vnútra Kaliňáka vystriedala požiadavka predčasných volieb. Je dôležité upozornit aj na to, že vztah, ktorý plávajúce signifikanty vytvára, sa odlišuje od vztahu charakteristického pre prázdne signifikanty. Táto odlišnost̉ sa dá vysvetlit nasledovne:

Zatímco prázdné signifikanty závisejí na plně rozvinuté vnitřní hranici, jež je výsledkem ekvivalenčního řetězce, plovoucí signifikanty jsou projevem nejednoznačnosti, jež je niterně vlastní všem hranicím, a neschopnosti těchto hranic dosáhnout jakékoli konečné stability. ${ }^{22}$

To znamená, že s plávajúcimi signifikantmi sa stretávame v prípade zmeny vnútornej hranice, t. j. v prípade reartikulácie požiadaviek. Je však dôležité

Tamtiež, s. 190. 
upozornit, že toto rozlíšenie je predovšetkým analytické. Prázdne a plávajúce signifikanty sa totiž v praxi do vel'kej miery navzájom prekrývajú. Faktom je, že spoločnost̉ sa nikdy nevyznačovala a ani nevyznačuje ustálenostou. Ona vnútorná hranica teda vždy môže podliehat̉ nejakému posunu. Takisto však platí, že žiadna spoločenská kríza nie je až tak hlboká, aby subverzívne tendencie z nej vyplývajúce neboli napokon do istej miery stabilizované. Táto stabilizácia môže nastat’ v prípade, ak vládnuca moc vyhovie niektorým požiadavkám l’udu a príjme zásadné opatrenia ako napr. výmena premiéra a rekonštrukcia vlády, odstúpenie policajného prezidenta, ba až predčasné vol'by.

Treba však podotknút, že s populizmom sa môžeme stretnút nielen v tej najvyššej politike, ale v ktorejkolvek oblasti spoločensko-inštitucionálnej štruktúry, ako sú napr. klientelisticko-politické organizácie, etablované politické strany, odpor armády či revolučných hnutí a i. Ako sme však na základe tu predstavenej analýzy mohli pozorovat', populizmus nedefinuje ich aktuálnu politiku, ale predstavuje spôsob artikulácie ich tém, a to nech už sú akékol'vek. Pýtame sa teda: Môže sa akýkol'vek politický subjekt za určitých okolností staţ populistickým? Avšak, z tu prezentovanej analýzy vyplýva, že by sme si mali skôr položit otázku takto:

Do jaké míry je nějaké hnutí populistické?23

Nejaké hnutie, strana či subjekt sa stáva populistickým práve do takej miery, do akej sú jeho obsahy artikulované v logike ekvivalencie, tzn. ako sú nesplnené požiadavky v rámci celého ich dlhého retazca predkladané inštitucionálnemu systému. Je potrebné ale upozornit tiež na skutočnost', že žiadne politické hnutie, strana či subjekt neexistuje úplne nezávisle od populizmu. Každé totiž interpretuje l'ud proti nejakému nepriatel'ovi. Opozícia zväčša proti vládnucej elite, ktorú l’udu vykresluje ako neefektívnu a netransparentnú, a koalícia naopak zase proti opozícii a všetkým tým, ktorí ju kritizujú a podla nich ešte viac polarizujú spoločnoste. Je to práve l’ud ako istá partikularita, ktorý je schopný prostredníctvom ekvivalenčných retazcov, t. j. retłazcov nesplnených požiadaviek, vytvorił’ niečo, čo reprezentuje spoločnost̉ ako celok. Skutočnostou ale je, že absolútne, trvalé, konečné spojenie tejto partikularity s univerzalitou nie je možné, pretože sa vždy medzi nimi objaví nejaká trhlina. A práve tak vzniká po-

Tamtiež, s. 192. 
litika. ${ }^{24}$ Ako upozorňuje Bíba, Laclau „vypracovává politickou gramatiku populismu, která, jak je přesvědčen, poskytuje nejenom lepší pochopení politiky, ale i politična jako takového“. ${ }^{25}$ To znamená, že „problematika populismu otevírá královskou cestu k pochopení podstaty politiky“. ${ }^{26}$

Úplne na záver nášho článku pojednávajúcom o analýze populizmu podla E. Laclaua sa pokúsime interpretovat jej základné tézy v kontexte súčasného diania na domácej i zahraničnej spoločensko-politickej scéne.

V prípade, že aplikujeme analýzu populizmu podla E. Laclaua na súčasnú spoločensko-politickú situáciu doma i v zahraničí, dospievame k záveru, že mnohé jej tézy by sa na ňu dali celkom jednoducho aplikovat.

Laclau podla nášho názoru jednoznačne pomenoval vznik populizmu. To znamená, v momente, ked' spoločenská frustrácia z neustále sa zväčšujúceho retazca nesplnených požiadaviek vygraduje až do takej miery, že vzniká medzi inštitucionálnym systémom, resp. vládnucou elitou, a l’udom spoločenská trhlina, môžeme pozorovat vznik populizmu. Dôkazom toho je v súčasnosti vel’mi napätá spoločensko-politická situácia nielen u nás na Slovensku, ale i v zahraničí. Táto celospoločenská frustrácia pramení jednak z procesu globalizácie, jednak zo samotného systému liberálnej demokracie. Spoločnost̉ je z nich totiž do vel'kej miery sklamaná, lebo globalizácia, ako i liberálna demokracia nenaplnili ich očakávania lepšieho života. Hoci globalizácia so sebou priniesla aj mnohé výhody (internet, nadnárodné spoločnosti, medzinárodné organizácie, projekt Európskej únie so spoločnou menou atd'.), tento proces spôsobil aj to, že kapitalizmus získal na sile, čo okrem určitých výhod znamená ešte hlbšie prehlbovanie sociálnych rozdielov medzi l'ud'mi. V súvislosti s liberálnym systémom konštatujeme, že na prvý pohlad sa môže javit ako dokonalý, no ak svoj zrak viac zaostríme, vidíme, že i liberálna demokracia môže prinášat niekol'ko závažných problémov prameniacich napr. z otázky tyranie väčšiny alebo problematiky slobody slova a prejavu. ${ }^{27} \mathrm{Ne}-$ ustále sa predlžujúci retazec nesplnených požiadaviek, ktoré sa predovšetkým týkajú zlepšenia kvality života l’udí, má tak za následok zväčšovanie

24 Pozri tamtiež, s. 188.

25 Jan Bíba, Úvod, in E. Laclau, Emancipace a radikálni demokracie..., s. 23.

26 Tamtiež, s. 23.

27 Táto problematika okrem iného súvisí aj s prejavom extrémizmu, ktorý môžeme pozorovat aj spolu s rozmachom internetu a sociálnych sietí. O tomto probléme však podrobnejšie pojednávame v inej práci. 
priepasti na hranici medzi „obyčajnými“ lud'mi a vládnucou elitou. Naopak, ked' vládnuca elita napr. v podobe príslušnej inštitúcie určitým požiadavkám vyhovie, táto hranica sa zúži, resp. priepast sa zmenšuje. Príkladom takejto situácie je napr. súčasné dianie na Slovensku. Po vražde novinára a jeho priatel'ky frustrácia a nespokojnost’ l’udí s neriešením ich požiadaviek vyvrcholila a pretavila sa do pochodov „Za slušné Slovensko“ nielen v mestách po Slovensku, ale i vo svete. Organizátori v mene spoločnosti vzniesli niekol'ko požiadaviek, avšak napokon len jedna zastala úlohu ich reprezentanta, t. j. prázdneho signifikantu - predčasné vol'by! Napokon prišlo k akémusi čiastočnému upokojeniu situácie po splnení niektorých z požiadaviek, tzn. hranica sa trošku zúžila. Napriek tomu je však situácia medzi l’udom a elitou nad’alej vel'mi napätá, čo samozrejme predstavuje úrodnú pôdu pre populizmus. Takisto neexistencia politických a voličských alternatív je d’alším zdrojom populizmu, pretože nie je možné dobre žit v spoločnosti, kde nejestvuje nádej na zmenu k lepšiemu. ${ }^{28}$ Ako príklad nám opät môže slúžit slovenská politická scéna. Smer sociálna demokracia na Slovensku vládne viac ako desat̉ rokov, pričom sa dokázala stat najsilnejšou stranou z pomedzi všetkých politických strán. Práve tento fakt je jednou z príčin roztrieštenosti slovenskej pravice. I súčasná vládna koalícia na čele so Smerom SD často argumentuje, že neexistuje žiadna iná alternatíva. Skutočnostou však je, že pod váhou mnohých káuz, z ktorých poslednou kvapkou je práve vražda novinára a jeho snúbenice ako aj informácie, ktoré novinár vo svojom poslednom nedokončenom článku zverejnil, t. j. údajné napojenie politických špičiek Smeru SD na taliansku mafiu, zapríčinili, že tejto vládnej strane začali klesat’ preferencie. Ak sa však pozrieme na súčasnú slovenskú opozíciu, je vel’mi otázne, či práve ona predstavuje tú správnu alternatívu. A preto v štáte, kde aj koalícia, aj opozícia polarizujú nespokojnú spoločnost’, sa populizmus ujíma až príliš lahko. Takýto vývoj však môže znamenat, že si spoločnost’ za svoju alternatívu zvolí radikálne až extrémistické politické subjekty, ktoré takisto do istej miery môžu využívat populizmus ako nástroj na upevnenie svojej pozície. To v konečnom dôsledku pre spoločnost̉ môže znamenat vel'ké riziko, a to iste väčšie než Smer SD pri moci d’alšie volebné obdobie.

28 Veronika Sušová-Salminem, Populismus - strašidlo, které kráčí Evropou, Argument 13. 3. 2017 [online, cit. 14. 3. 2018], dostupné na <http://casopisargument.cz/2017/03/13/populismus-strasidlo-ktere-kraci-evropou/>. 
Vzhladom na vyššie uvedené skutočnosti však niet pochýb o tom, že dnešná spoločnost̉ si žiada zmenu. Jednoducho hladá istú alternatívu k súčasnému jej už nevyhovujúcemu politickému systému. Populizmus touto alternatívou nie je. Je to len nástroj, ako túto alternatívu dosiahnut. Populizmus sa tak stáva pokusom o obrodenie politiky. To samozrejme nie je zlou cestou, avšak otázkou zostáva, čo nás na jej konci čaká. Populizmus sa dnes ale uberá cestou podnecovania nenávisti, tzn. radikalizmu, ba až extrémizmu, a tým i vytvárania ešte väčšej priepasti medzi l'ud’mi. A to je rozhodne zlá cesta!

\section{Mgr. Barbara Biháryová}

Filozofická fakulta, Univerzita Komenského v Bratislave

Gondova 2, 81499 Bratislava, Slovenská republika

biharyova2@uniba.sk 
